\title{
A case study of an organic Agripreneur adopting integrated farming system model at Kullagoundenpudur village of Erode district in Tamil Nadu, India
}

N. Dhivya*

Department of Social Sciences, Agricultural College and Research Institute, Tamil Nadu Agricultural University, Killikulam- 628252 (Tamil Nadu), India

\section{Karthikeyan}

Department of Social Sciences, Agricultural College and Research Institute, Tamil Nadu Agricultural University, Killikulam- 628252 (Tamil Nadu), India

*Corresponding author. Email: dhivyanatarajan1198@gmail.com

\section{Article Info}

https://doi.org/10.31018/ jans.v13iSI.2822 Received: March 22, 2021 Revised: May 30, 2021 Accepted: June 14, 2021

\section{How to Cite}

Dhivya, N. and Karthikeyan, C. (2021). A case study of an organic Agripreneur adopting integrated farming system model at Kullagoundenpudur village of Erode district in Tamil Nadu, India. Journal of Applied and Natural Science, 13 (SI), 162 - 166. https://doi.org/10.31018/jans.v13iSI.2822

\begin{abstract}
The present study aimed to investigate the profile characteristics, key facts, and figure by identifying an enterprising organic farmer among many farming groups. The case study method which is a comprehensive study of a social unit comprised of a person, a group, a social institution, a district, or a community was followed to study the selected organic farmer cum agripreneur who effectively used all his farm resources less input usage drawn outside his farm. One of those differed from other organic farmers to integrate all his farm components and carried out farming activity with future market forecast into mind. In addition to that, his farm, which was located in Kullagoundenpudur village of Erode district in Tamil Nadu, had been approved as 'Model Farm' on Integrated Farming System (IFS). There existed great scope for doing agriculture as a business activity in future. His business motive, risk-bearing nature and time management strategy helped him to succeed in his business. He also coined that for his success, "Genetics played $60 \%$ role, Technology played $20 \%$ role and Management played $20 \%$ role". The study will also motivate young graduates and other farmers to come forward and adopt such farming activities.
\end{abstract}

Keywords: Case study, Crop productivity, Integrated farming system, Organic farming

\section{INTRODUCTION}

India is an agriculture-based country. In recent days, organic farming has been gaining more awareness and importance among the farming community. Organic farming involves holistic production systems that avoid synthetic fertilizers, pesticides, and genetically modified organisms, thereby minimizing their deleterious effect on the environment (Behera et al., 2012). An increase in awareness and concern about the impact of synthetic chemicals in agriculture has been major drivers for increasing consumer demand for organic foods (Baranski et al.,2014). Organically grown produce is considered environmentally safer and more nutritious than conventionally grown produce (Williams and Hammitt, 2001). Diversification in agriculture commonly means different growing crops instead of concentrating on a single crop. Integrated farming system based on experiences from Tamil Nadu, India, described these systems as a mixed animal crop system where the animal is used to cultivate the soil and provide manure to be used as fertilizer and fuel (Jayanthi et al., 2000). Rapid economic and income growth, urbanization, and globalization are leading to a dramatic shift of Asian diets away from staples and increasingly towards livestock and dairy products, vegetables and fruit, fats and oils (Pingali, 2004). Under the gradual shrinking of land holding, it is necessary to integrate land-based enterprises like fishery, poultry, field and horticultural crops within the farmers' bio-physical and socio-economic environment to make farming more profitable and dependable (Behera et al., 2004).

An entrepreneur is the one who organizes, manages and assumes the risks of a business or enterprise. En- 
trepreneurial opportunities differ from normal possibilities to optimize the efficiency of existing products in the sense that the former involves new means-ends relationships (Davidsson, 2015). Agricultural entrepreneurs are those who undertake agricultural activities through mechanization, irrigation and the application of technologies to produce the crop. They covered a broad spectrum of the agricultural sector and included agriculture and allied occupations (Rai et al., 2017).

This research aimed to identify the remarkable organic farmer among many farming groups who can serve as a role model for the youth and other venturing farmers in society. The study also aimed to identify the successful farmer's profile characteristics and narrate the key facts and figures that supported the success of an Agripreneur.

\section{MATERIALS AND METHODS}

The case study method is a comprehensive study of a social unit comprised of a person, a group, a social institution, a district or a community (Young, 1996). It is the social microscope, as stated by Burgess (1993). A case study method was followed to study the organic farmer, and an Agricultural entrepreneur hailed from Kullagoundenpudur village of Erode district in Tamil Nadu. He was purposively selected for the study because of the following uniqueness possessed by him: a Research Council Member of Tamil Nadu Veterinary and Animal Sciences University, Chennai; got awards from Tamilnadu government for his Indigenous Kangeyam cow during 2014 and Best Piggery farmer award during 2016. The entrepreneur was personally interviewed and data was collected with the help of a semistructured interview schedule.

\section{RESULTS}

\section{Profile}

Health is wealth for the selected agripreneur, 52 years old with an educational qualification up to tenth standard (SSLC). He was doing organic farming in an integrated way in his own land area of about 16 hectares at Kullagoundenpudur village, Unjalur (Po), Erode district. Farming has been carried out traditionally and it was his full-time main occupation and he possessed 30 years of farming experience. He lived in a nuclear family with his wife and a daughter and earned a profit of about rupees thirty lakhs per annum. He was highly interested in doing innovative organic farming in an integrated manner and had risk-bearing qualities, timely management and market forecast sensing ability which helped him to succeed in his agribusiness. The fact which made him to enter into integrated organic farming was the increased cost of inputs and labour.

\section{Entry into agriculture}

The entrepreneur had entered into farming which has been carried out traditionally by his forefathers with their owned land, Native cattle's (Kangayam) and Desi poultry unit in the year 1984 with an educational qualification up to tenth standard (SSLC). During those days, he felt that a major part of the cost of cultivation was attributed in the form of labour charge. Then he started the Goat rearing unit in an organic way with a motive: "Work done by one should not damage others' life". In those days, the price of goat meat was Rs.23/kg. The cross from Nellore Judipi and Russian White were being reared. Then he started Coconut Nursery and named his farm as "Sri Amman coconut nursery and animal husbandry farm". He also started rearing Ducks, the cross from Sara and Sembli and the major crops produced on his farm were traditional variety rice, turmeric, banana and fodder grass (Napier).

\section{Decision towards the establishment of Piggery unit}

Due to drought and water scarcity in 2009 , he lost most of his coconut crop and could not continue duck rearing. Then he switched over to Piggery unit. The motivational fact that derived him to start the piggery unit was that the world's largest consuming meat is Pork with an average of 40.2 per cent of the total world population. Also, it has a good dressing percentage (The percentage of the live animal weight that becomes the carcass weight at slaughter). He started rearing three breeds of the pig; they are Large White Yorkshire, Landrace and Duroc. Considering his excellent services in animal husbandry, he was selected as a Research Council member by Tamilnadu Veterinary and Animal Sciences University. In addition to that, his farm has been approved as Integrated Farming System (IFS) Model Farm by Tamil Nadu Veterinary and Animal Sciences University in the year of 2013. He also started producing liquid organic manure with all his farm waste and used it as fertilizer. He states that it has boosted the crop resistance level and increased shelf-life of farm produce. He sold the liquid organic manure at the rate of Rs.4/litre to other farmers

During 2019, the components in his farm were Paddy (traditional variety), Banana, Coconut, Turmeric, Poultry unit (Desi chick), Native Cattle (Kangeyam), Piggery unit, Fodder grass (Napier) and Goat rearing. He had effectively utilized the resources of his farm by following crop rotation and also by decomposing waste from his farm animals and utilizing it as fertilizers for the crops to increase its production. The usage of liquid organic manure also controlled pest and disease incidence, and no other chemicals were used in his field for crop protection. The farm animals were given organic feed, mostly produced in his farm and vaccinated at the proper time. A separate shed has been established for cat- 
Dhivya, N. and Karthikeyan, C. / J. Appl. \& Nat. Sci. 13 (SI), 162 - 166 (2021)

tle and pigs; cages for desi chicken. He had four fulltime labourers for the maintenance work of his farm. Most of his farm products were sold within the region, and if anything goes in excess, it was sent to the Kerala market.

The details regarding the economics of his Integrated Farming System farm (Crop + Dairy + Poultry + Goat + Piggery) is presented in table 1 . It was noted that the farmer had spent rupees Ten lakhs as his initial investment towards the establishment of sheds for his farm livestock's and selection of breed. After that, the farmer had undertaken farm maintenance activities such as timely vaccination for livestock enterprises, crop rotation and other intercultural operations in farm to a tune of rupees nine lakhs per annum. He earned an average minimum income of rupees Thirty lakhs per annum. Thus the net profit works out to five to six per cent per annum and the Benefit-Cost ratio of the Integrated Farming System (IFS) adopted by the case was 1:1.58.

\section{Process of producing liquid organic manure}

$\mathrm{He}$ had constructed an underground tank with three compartments consisting of a vent at the bottom. The first compartment was loaded with farm waste, biodecomposers with other beneficial microbes. The second compartment consists of partially decomposed matters that are filtrate from the first compartment which was collected through the interconnected vent in the tank. The third compartment consists of the decomposed sludge, which was the second compartment's filtrate and then loaded with beneficial microbes. The enriched decomposed sludge was the liquid organic manure. He added that the methane produced during this process had been oxidized. The farm waste utilized for the production of liquid organic manure was as i) Cow dung and Urine, ii)Pig urine and Dung, iii)Pig fat, iv) Bone waste from farm animals, v) Fish waste, vi) Waste decomposer, vii)Waste milk products, viii)Fruit and vegetable waste, ix) Beneficial Microorganisms.

\section{Use of biofertilizers and microbial cultures}

Biofertilizers like Rhizobium, Azotobacter, Azospirillum and Pseudomonas etc have been found to be very effective tools of fertility management and biological nutrient mobilization. Recently customized consortia of such biofertilizer organisms, better adapted to local climatic conditions, have also been developed and are available commercially. The efficiency of such microbial formulations is much higher under no-chemical use situations. Therefore the application of such inputs needs to be ensured under all cropping situations (Kumar et al., 2017).

\section{Crop rotation}

Crop rotation is the backbone of the organic farming practice, which is followed to keep the soil healthy and
Table 1. Economics of integrated farming system model farm.

\begin{tabular}{ll}
\hline Particulars & Rupees \\
\hline Initial Investment & Rs. $10,00,000$ \\
Maintenance cost per annum & Rs. 9,00,000 \\
Income per annum & Rs.30,00,000 \\
B:C ratio & $1: 1.58$ \\
\hline
\end{tabular}

Table 2. Effects of green manure in crop rotation.

\begin{tabular}{lll}
\hline Crop & Productivity (T/ Ha) & Nitrogen \% \\
\hline Subabul & $09-12$ & $0.80-0.90$ \\
Sunhemp & $12-13$ & $0.43-0.45$ \\
Dhaincha & $20-22$ & $0.43-0.45$ \\
Cowpea & $15-16$ & $0.49-0.49$ \\
Clusterbean & $20-22$ & $0.34-0.51$ \\
\hline
\end{tabular}

Source: Kumar et al. (2017)

Table 3. Quantity of $\mathrm{N}$ fixed by legumes.

\begin{tabular}{ll}
\hline Crop & N Fixed (kg/ha) \\
\hline Cowpea & $80-90$ \\
Clusterbean & $40-200$ \\
Fenugreek & 45 \\
Pea & $50-60$ \\
Chickpea & $85-100$ \\
\hline
\end{tabular}

Source: Palaniappan and Annadurai (1999).

allow the natural microbial systems to work effectively. Crop rotation refers to the succession of different crops cultivated on the same land, which improves soil conditions. It involves the follow up of a 3-4 years rotation plan. Green manure crops should also find a place in planning rotations. All high nutrient demanding crops should precede and follow legume-dominated crop combinations, which means legumes should be in rotation with cereals and vegetable crops. It promotes the productivity and fertility of the soil. Rotation of pest host and non-pest host crops helps in controlling soil-borne diseases and pest. Crop rotations help in improving soil structure through different types of the root system. It also helps in controlling weeds.

The details regarding the additional benefit in productivity of land and increased nitrogen of the soil by the addition of green manures in crop rotation given by Kumar et al. (2017) is furnished in Table 2, and the information regarding the quantity of nitrogen fixed in the soil by use of different legume crops during crop rotation as interpreted by Palaniappan and Annadurai (1999) from their studies is presented in Table 3.

\section{Milestones achieved from the case studies}

In 2014, the indigenous (Kangeyam) cattle from his farm had won the 1st and 2nd prize from Government 
of Tamilnadu, India.

In 2016, his piggery farm was awarded as 'Best Piggery Farm' by the Government of Tamil Nadu, India.

\section{Message to future generation}

The youth should have a broad thinking mind as the world is globalized there are vast marketing opportunities. They should stand on their own without expectations from others. There exists vast scope of entrepreneurship in agriculture across the food chain. One must understand the ground nature, its technical aspects and management aspects. He also quoted that "Success is a result of continuous hard work and it is not a single day dream; it's the result after some failures which teaches you more lessons".

This case study research implies that there exists great scope for agriculture in future. One should understand the nature and market demand before starting anything; whatever activities he/she follows should be in a focused and well-planned manner. He stated that for his success, "Genetics played $60 \%$ role, Technology played $20 \%$ role and Management played $20 \%$ role". Here he emphasised 'Genetics' as the selection of varieties and breeds, 'Technology' as the method of cultivation with understanding of ground nature and 'management' as the farm's timely monitoring and management strategy. His business motive, riskbearing nature and management strategy made him to succeed in agriculture. One can succeed only through their experience and hard work in any field. His future plan was to develop his farm and also to provide training for those who approached him. He added that those who did farming should understand the market situation, analyze the demand and produce according to the market demand. This case study finding will motivate young farm graduates and other farmers to come forward and adopt such farming activities.

\section{DISCUSSION}

Integration of allied activities results in the availability of nutritious food enriched with protein, carbohydrate, fat, minerals and vitamins for all the lives involved in this "web of life" including humans. Integrated farming helps in environmental protection through effective recycling of waste from animal activities. The reduced production cost of components through input recycling from the by-products of allied enterprises makes him get regular stable income through the products throughout the year though one or two enterprise failed due to vagaries of monsoon (TNAU Agritech Portal, 2014). This case study was also similar to the success story of Mr. Hebbar, who earns a net annual income of around Rs. 3.5 lakhs as integrative farming ensures 90 per cent of nutrient requirement through bio-mass pro- duced in the farm itself, one of the basic ingredient of organic farming practices (Staff Reporter, 2016). The Agriculture Department of Tamil Nadu, in association with the Horticulture and Animal Husbandry Departments, will implement the Integrated Farming System (IFS) phase III under the National Agriculture Development Project, which seeks to promote a holistic approach to farming, would encourage beneficiaryfarmers to take up a host of allied activities towards doubling their income (Ganesan, 2020). Rice-based cultivation offers immense potential for food security and poverty alleviation in rural areas. This IFS methodology may change rural advancement by agricultural development in the 21st century to make India a developed nation (Rautaray, 2013).

\section{Conclusion}

With an increasing demand for organic products, most farmers started shifting towards organic farming and it is also important to meet the food needs of this growing population. The integrated farming system played a significant role in the effective management of available resources at the farm level by generating adequate income and employment for the rural poor and sustainably improving their livelihoods throughout the year. This case study findings showed the success of the Integrated Farming System (IFS) model followed by the entrepreneur, where he integrated all the components of his farm and effectively used it with proper planning and management. It is a proficient method of utilizing the same land asset to deliver both carbohydrates and animal protein simultaneously or sequentially. The nutrients and mineral prerequisites were met by developing vegetables and organic products on bunds, thus providing a balanced diet to a farm family, reducing hunger and malnutrition. There is a need to explore the synergistic interactions of the components of farming systems to enhance resource-use efficiency and recycling of farm by-products. Hence this study will be useful for young farm graduates and other farmers to come forward and adopt such farming activities in a scientific and well-planned manner.

\section{ACKNOWLEDGEMENTS}

I would like to express my special thanks of gratitude to the organic farmer cum Agripreneur Mr. K.A. Sathyamoorthy for sharing his knowledge and experience. The author has the consent of publishing his technology of farming.

\section{Conflict of interest}

The authors declare that they have no conflict of interest. 


\section{REFERENCES}

1. Baranski, M., Srednicka-Tober, D. , Volakakis, N., Seal, C., Sanderson, R. , Stewart, G.B. \& Leifert, C. (2014). Higher antioxidant and lower cadmium concentrations and lower incidence of pesticide residues in organically grown crops: a systematic literature review and metaanalyses. British Journal of Nutrition, 112(5), 794-811 . doi: $10.1017 / \mathrm{s} 0007114514001366$.

2. Behera, K. K., Alam, A., Vats, S., Sharma, H. P. \& Sharma, V. (2012). Organic farming history and techniques. agroecology and strategies for climate change. Sustainable Agriculture Reviews, 287-328 doi: 10.1007/978-94007-1905-7_12

3. Behera, U. K., Jha, K. P. \& Mahapatra, I.C. (2004). Integrated management of available resources of the small and marginal farmers for generation of income and employment in eastern India. Crop Research, 27 (1), 83-89

4. Burgess (1993). Research Methods in Sociology. Georges Gurvitch and W.E. Moore (Eds.) Twentieth Century Sociology. p.26

5. Davidsson, P. (2015). Entrepreneurial opportunities and the entrepreneurship nexus: A reconceptualization. Journal of Business Venturing, 30(5), 674-695. doi:10.1016/ j.jbusvent.2015.01.002

6. Ganesan. S (2020). Integrated farming system to be promoted in seven central districts. THE HINDU. Retrived from https://www.thehindu.com/news/cities/Tiruchirapalli/ integrated-farming-system-to-be-promoted-in-sevencentral-districts/article31759287.ece

7. Jayanthi, C., Rangasamy, A. \& Chinnusamy, C. (2000). Water budgeting for components in lowland integrated farming systems. Agriculture Journal, 87, 411-414.
8. Kumar, R., Singh, S., Krishna, K.R., Anokhe, A. \& Prakash, N.R. (2017). Organic farming of vegetables: Prospects and scenario. Global Journal of Bio-Science and Biotechnology, 6(2), 390-394.

9. Palaniappan, S.P. \& Annadurai, K. (1999).Organic Farming Theory and Practice, Scientific Publications, Jodhpur, India.

10. Pingali, P. (2004). Agricultural diversification: Opportunities and constraints. FAO Rice Conference

11. Rai. C.K., Arti \& Abul K. Azad. (2017). Agri-Preneurship: Need of the Hour. Biotech Articles.https://www.biotech articles.com/Agriculture-Article/Agri-Preneurship-Need-ofthe-Hour-4113.html

12. Rautaray, S. (2013). Integrated farming system research in India: An overview. Integrated Farming Systems for livelihood security of small and marginal farmers, Division of Agronomy, IARI, New Delhi, pp. 1-38.

13. Staff Reporter (2016). Farmer's success story through integrated farming. THE HINDU. Retrieved from https:// www.thehindu.com/news/national/kerala/farmers-successstory-through-integrated-farming/article2788078.ece

14. TNAU Agritech Portal (2014). Success stories : Animal husbandry - integrated farming system ensures biodiversity. Retrieved from https://agritech.tnau.ac.in/succe ss_stories/sstories_ahus_2015_integrated_farming. html

15. Williams, P.R. and Hammitt, J. K. (2001). Perceived risks of conventional and organic produce Pesticides, pathogens and natural toxins. Risk Anal. 21, 319-330.

16. Young, P.V. (1996). Scientific social surveys and research: An introduction to the background, content, methods, principles and analysis of social studies. $4^{\text {th }}$ ed., Englewood Cliffs, N.J.: Prentice-Hall. p.247 ISBN 10: 0137965087 ISBN 13:978013796508 